\title{
ANALISIS KELAYAKAN PEMBIAYAAN BANK SYARIAH
}

\author{
Rahmat Ilyas \\ IAIN Syaikh Abdurrahman Siddik Bangka Belitung
}

Email: rahmatilyas82@gmail.com

\begin{abstract}
Sharia banks are banks that operate by not relying on interest. Islamic banks or commonly referred to as a bank without interest, is a financial institution / banking operational and its products are developed based on al-Qur'an and hadith. Financing is one of the principal tasks of banks, namely the provision of facilities to provide funds to meet the needs of the parties which is the unit deficit. The main purpose of the financing analysis is to gain confidence whether the customer has the willingness and ability to fulfill his obligations in an orderly manner, both principal and profit sharing in accordance with the agreement with the bank.
\end{abstract}

Keywords: sharia banks, financing

\begin{abstract}
Abstrak
Bank syariah adalah bank yang beroperasi dengan tidak mengandalkan pada bunga. Bank Islam atau biasa disebut dengan bank tanpa bunga, adalah lembaga keuangan/perbankan yang operasional dan produknya dikembangkan berdasarkan pada al-qur'an dan hadist. Pembiayaan merupakan salah satu tugas pokok bank, yaitu pemberian fasilitas penyediaan dana untuk memenuhi kebutuhan pihak-pihak yang merupakan defisit unit. Tujuan utama dari analisis pembiayaan adalah memperoleh keyakinan apakah customer punya kemauan dan kemampuan memenuhi kewajibannya secara tertib, baik pembayaran pokok pinjaman maupun bagi hasil sesuai dengan kesepakatan dengan bank
\end{abstract}

Kata kunci: bank syariah, pembiayaan.

\section{A. PENDAHULUAN}

Perbankan Islam sekarang ini telah dikenal secara luas dibelahan dunia muslim dan barat. Perbankan Islam merupakan bentuk perbankan dan pembiayaan yang berusaha memberi pelayanan kepada nasabah dengan bebas bunga (interest). Para perintis perbankan Islam berargumen 
bahwa bunga (interest) termasuk riba, dan jelas-jelas dilarang dalam hukum Islam. Alasan tersebut mendorong beberapa sarjana muslim dan para penanam modal untuk menemukan alternatif lain cara pengembangan sistem perbankan yang sesuai dengan aturan hukum Islam, khususnya yang berkaitan dengan larangan riba.

Bank syariah adalah bank yang beroperasi dengan tidak mengandalkan pada bunga. Bank Islam ataau biasa disebut dengan bank tanpa bunga, adalah lembaga keuangan/perbankan yang operasional dan produknya dikembangkan berdasarkan pada al-qur'an dan hadist. Dengan kata lain bank Islam adalah lembaga keuangan yang usaha pokoknya memberikan pembiayaan dan jasa-jasa lainnya dalam lalu lintas pembayaran serta peredaran uang yang pengoperasiannya disesuaikan dengan prinsip-prinsip syariat Islam.

Bank sebagai lembaga perantara jasa keuangan (financial Intermediary) yang tugas pokoknya adalah menghimpun dana dari masyarakat, diharapkan dengan dana dimaksud dapat memenuhi kebutuhan dana pembiayaan yang tidak disediakan oleh dua lembaga sebelumnya baik lembaga negara mapun swasta.

Dalam kegiatan penyaluran dana bank syariah melakukan investasi dan pembiayaan. disebut investasi karena prinsip yang digunakan adalah prinsip penanaman dana atau penyertaan, dan keuantungan akan diperoleh bergantung pada kinerja usaha yang menjadi obyek penyertaan tersebut sesuai dengan nisbah bagi hasil yang diperjanjikan sebelumnya. disebut pembiayaan karena bank syariah menyediakan dana guna membiayai kebutuhan nasabah yang memerlukannya dan layak memperolehnya. ${ }^{1}$

1 Rahmat Ilyas, Kontrak Pembiayaan Murabahah Dan Musawamah, Jurnal BISNIS, Vol. 3, No. 2, Desember 2015, hlm. 291 


\section{B. PENGERTIAN PEMBIAYAAN}

Para teoritikus perbankan Islam mendambakan aktivitas investasi dalam bank Islam didasarkan pada dua konsep yang legal, yaitu mudharabah dan musyarakah, sebagai alternatif dalam menerapkan sistem bagi hasil (profit and loss sharing). Teori ini menyatakan bahwa bank Islam akan memberikan sumber pembiyaan (finansial) yang luas kepada peminjam (debitur) berdasarkan atas bagi resiko (baik yang menyangkut keuntungan maupun kerugian), yang berbeda dengan pembiayaan (finansial) sistem bunga pada dunia perbankan konvensional yang semua resikonya ditanggung oleh pihak peminjam (debitur). ${ }^{2}$

Dalam masyarakat Indonesia, selain dikenal istilah utang-piutang, juga dikenal istilah kredit dalam perbankan konvensional dan istilah pembiayaan dalam perbankan syari'ah. Utang-piutang biasanya digunakan oleh masyarakat dalam konteks pemberian pinjaman kepada pihak lain. Seseorang yang meminjamkan hartanya kepada orang lain, maka ia dapat disebut telah memberikan utang kepadanya. Adapun istilah kredit atau pembiayaan lebih banyak digunakan oleh masyarakat pada transaksi perbankan dan pembelian yang tidak dibayar secara tunai. Secara esensial, antara utang dan kredit atau pembiyaan tidak jauh berbeda dalam pemaknaannya di masyarakat. ${ }^{3}$

Pembiayaan atau financing, yaitu pendanaan yang diberikan oleh suatu pihak kepada pihak lain untuk mendukung investasi yang telah direncanakan, baik dilakukan sendiri maupun lembaga. Dengan kata lain, pembiayaan adalah pendanaan yang dikeluarkan untuk mendukung investasi yang telah direncanakan. ${ }^{4}$

2 Abdullah Saed, Bank Islam dan Bunga: Studi Kritis dan Interpretasi Kontemporer tentang Riba dan Bunga, (Yogyakarta:Pustaka Pelajar, 2008), hlm. 90.

${ }^{3}$ Rahmat Ilyas, Konsep Pembiayaan Dalam Perbankan Syari'ah, Jurnal Penelitian, Vol. 9, No. 1, Februari 2015, hlm. 185.

${ }^{4}$ Muhammad, Manajemen Pembiayaan Bank Syariah, (Yogyakarta, UPP AMP YKPN, 2005), hlm. 17 . 
Sedangkan dalam undang-undang nomor 21 tahun 2008 disebutkan bahwa Pembiayaan adalah penyediaan dana atau tagihan yang dipersamakan dengan itu berupa:

1. Transaksi bagi hasil dalam bentuk mudharabah dan musyarakah;

2. Transaksi sewa-menyewa dalam bentuk ijarah atau sewa beli dalam bentuk ijarah muntahiya bittamlik;

3. Transaksi jual beli dalam bentuk piutang murabahah, salam, dan istishna;

4. Transaksi pinjam meminjam dalam bentuk piutang qardh; dan

5. Transaksi sewa-menyewa jasa dalam bentuk ijarah untuk transaksi multijasa berdasarkan persetujuan atau kesepakatan antara Bank Syariah dan atau UUS dan pihak lain yang mewajibkan pihak yang dibiayai dan atau diberi fasilitas dana untuk mengembalikan dana tersebut setelah jangka waktu tertentu dengan imbalan ujrah, tanpa imbalan, atau bagi hasil. ${ }^{5}$

\section{JENIS-JENIS PEMBIAYAAN}

Pembiayaan merupakan salah satu tugas pokok bank, yaitu pemberian fasilitas penyediaan dana untuk memenuhi kebutuhan pihakpihak yang merupakan defisit unit. Menurut sifat penggunaannya pembiayaan dapat dibagi menjadi dua hal berikut:

1. Pembiayaan produktif, yaitu pembiayaan yang ditujukan untuk memenuhi kebutuhan produktif dalam arti luas, yaitu untuk peningkatan usaha, baik usaha produksi, perdagangan maupun investasi.

2. Pembiayaan konsumtif, yaitu pembiayaan yang digunakan untuk memenuhi kebutuhan konsumsi, yang akan habis digunakan untuk memenuhi kebutuhan.

${ }^{5}$ Undang-undang Nomor 21 Tahun 2008 tentang Perbankan Syariah 
Menurut keperluannya, pembiayaan produktif dapat dibagi menjadi dua hal berikut:

1. Pembiayaan modal kerja, yaitu pembiayaan untuk memenuhi kebutuhan.

a. Peningkatan produksi, baik secara kuantitatif, yaitu jumlah hasil produksi, maupun secara kualitatif yaitu peningkatan kualitas mutu hasil produksi.

b. Untuk keperluan perdagangan atau peningkatan utility of place dari suatu barang.

2. Pembiayaan investasi yaitu untuk memenuhi kebutuhan barang-barang modal (capital goods) serta fasilitas-fasilitas yang erat kaitannya dengan itu. 6

Jenis pembiayaan pada bank syariah akan diwujudkan dalam bentuk aktiva produktif dan aktiva tidak produktif, yaitu:

1. Jenis aktiva produktif pada bank syariah, dialokasikan dalam bentuk pembiayaan sebagai berikut:

a. Pembiayaan dengan prinsip bagi hasil yang meliputi:

1) Pembiayaan Mudharabah

Pembiayaan Mudharabah adalah suatu kontrak kemitraan (partnership) yang berlandaskan pada prinsip pembagian hasil dengan cara seseorang memberikan modalnya kepada yang lain untuk melakukan bisnis dan kdua belah pihak membagi keuntungan atau memikul beban kerugian berdasarkan isi perjanjian bersama. Pihak pertama, suplier atau pemilik modal disebut dengan mudharib dan pihak kedua pemakai atau pengelola atau penguasa disebut dengan dharib. Dengan demikian mudharabah merupakan kemitraan antara penyumbang modal, pada satu pihak dan pemakai modal dipihak lain. Seseorang menyumbangkan modalnya dan yang lain sebagai pekerjanya yang berkemampuan, kemauan usaha serta kemampuan mengelola, dan menurut isi kontrak mutual

${ }^{6}$ Muhammad Syafi'i Antonio, Bank Syariah dari Teori ke Praktik, (Jakarta, Gema Insani Press, 2001), hlm. 160 
yang telah disepakati pembagian keuntungan bagi keduanya yaitu mudharib menerima $60 \%$ dan dharib menerima $40 \%$ atau dengan persentase lain yang mereka sepakati. ${ }^{7}$

2) Pembiayaan Musyarakah

Pembiayaan Musyarakah atau syirkah yaitu suatu perjanjian usaha antara dua atau beberapa pemilik modal untuk menyertakan modalnya pada suatu proyek, dimana masingmasing pihak mempunyai hak untuk ikut serta, mewakilkan, atau menggugurkan haknya dalam manajemen proyek. Keuntungan dari hasil usaha bersama ini dapat dibagikan baik menurut proporsi penyertaan modal masing-masing maupun sesuai dengan kesepakatan bersama (unproporsional). Manakala merugi kewajiban hanya terbatas sampai batas modal masingmasing. 8

b. Pembiayaan dengan prinsip jual beli yang meliputi:

1) Pembiayaan Murabahah

Pembiayaan murabahah adalah akad jual beli barang dengan menyatakan hargaa pokok perolehan dan keuntungan (margin) yang disepakati oleh penjual dan pembeli. Akad ini merupakan salah satu bentuk natural certainty contratcs, karena dalam murabahah ditentukan berapa required of profit-nya (keuntungan yang ingin diperoleh). Karena dalam defenisinya disebut adanya "keuntungan yang disepakati" karakteristik murabahah adalah sipenjual harus memberitahu pembeli tentang harga pembelian barang dan menyatakan jumlah keuntungan yang ditambahkan pada biaya tersebut. ${ }^{9}$

2) Pembiayaan Salam

Salam merupakan bentuk jual beli dengan pembayaran dimuka dan penyerahan barang dikemudian hari (advanced payment atau forward buying atau future sales) dengan harga, spesifikasi, jumlah, kualitas, tanggal dan tempat penyerahan

7 Afzalur Rahman, Doktrin Ekonomi Islam, Jilid 4, (Yogyakarta, PT. Dana Bhakti Wakaf, 1995), hlm. 380

${ }^{8}$ Karnaen Perwataatmadja \& Muhammad Syafi'I Antonio, Apa \& Bagaimana Bank Islam, (Yogyakarta, PT. Dana Bhakti Prima Yasa, 1992, hlm. 23

9 Adiwarman Karim, Bank Islam: Analisis Fiqih dan Keuangan, (Jakarta, PT. RajaGrafindo Persada, 2006), hlm. 113 
yang jelas, serta disepakati sebelumnya dalam perjanjian. ${ }^{10}$ Barang yang diperjual belikan belum tersedia pada saat transaksi dan harus diproduksi terlebih dahulu, seperti produk-produk pertania, dan produk-produk fungible (barang yang dapat diperkirakan dan diganti sesuai berat, ukuran dan jumlahnya) lainnya. Barang-barang non-fungible seperti batu mulia, lukisan berharga, dan lain-lain yang merupakan barang langka tidak dapat dijadikan sebagai objek salam. ${ }^{11}$

3) Pembiayaan Istishna

Istishna adalah jual beli dalam bentuk pembuatan barang tetentu dengan kriteria dan persyaratan tertentu yang disepakati antara pemesan (pembeli) dan penjual (pembuat). Pembeli dalam akad istishna tidak mewajibkan bank untuk membuat sendiri barang pesanan, maka untuk memenuhi kewajiban pada akad pertama, bank dapat mengadakan akad istishna kedua dengan pihak ketiga (subkontraktor). Akad istishna kedua ini disebut dengan istishna paralel. Menurut jumhur ulama, istishna sama dengan salam yaitu dari segi objek pesanannya yaitu harus dibuat atau dipesan terlebih dahulu dengan ciri-ciri khusus. Perbedaannya hanya pada sistem pembayaran, salam pembayarannya dilakukan sebelum barang diterima dan istishna bisa diawal, ditengah atau di akhir pesanan. ${ }^{12}$

c. Pembiayaan dengan prinsip sewa meliputi:

1) Pembiayaan Ijarah

2) Pembiayaan Ijarah Muntahiya Bittamlik

3) Surat berharga Syariah

4) Penempatan

5) Penyertaan Modal

6) Penyertaan Modal Sementara

7) Sertifikat Wadiah Bank Indonesia

\footnotetext{
${ }^{10}$ Ascarya, Akad \& Produk Bank Syariah, (Jakarta, PT. RajaGrafindo Persada, 2011), hlm. 90 ${ }^{11}$ Ibid

${ }^{12}$ Muhammad, Model-model Akad Pembiayaan di Bank Syariah, (Yogyakarta, UII Press, 2009), hlm. 87
} 
2. Jenis aktiva tidak produktif yang berkaitan dengan pembiayaan adalah berbentuk pinjaman yang disebut dengan pinjaman Qardh. Qardh bukan transaksi komersial, maka dana yang digunakan untuk penyaluran dana ini harus berasal dari dana sosial juga seperti zakat, infaq, shadaqah (ZIS). Jadi pembiayaan qardh adalah semata-mata produk bank yang dalam fungsinya untuk menjalankan kegiatan sosial. ${ }^{13}$

\section{TUJUAN DAN PRINSIP ANALISIS PEMBIAYAAN}

Perbankaan sebagai lembaga yang melaksanakan tiga fungsi utama, yakni menerima simpanan uang, meminjamkan uang dan memberikan layanan jasa perbankan. Di dalam sejarah perekonomian kaum muslimin fungsi-fungsi bank telah dikenal sejak zaman rasulullah saw. Fungsi-fungsi tersebut adalah menerima titipan harta, meminjamkan uang untuk keperluan konsumsi dan keperluan bisnis serta melakukan pengiriman uang.

Tujuan utama dari pendirian bank Islam adalah untuk menyebarkan kesejahteraan ekonomi dengan menerapkan kerangka Islam dalam sektor bisnis. Beberapa tujuan utama bank Islam yaitu:

1. Menunjang pelaksanaan pembangunan nasional dalam rangka meningkatkan keadilan, kebersamaan dan pemerataan kesejahteraan rakyat.

2. Menawarkan jasa keuangan: bank Islam memegang teguh peraturan dan prinsip syariah Islam untuk transaksi keuangan, dimana riba dan gharar semuanya merupakan hal yang dilarang dalam Islam. Kepercayaannya ditujukan pada pembiayaan yang berdasarkan pembagian risiko dan berfokus pada aktivitas yang dilahalalkan. Fokusnya adalah menawarkan transaksi perbankan berlandaskan

13 Tim Pengembangan Perbankan Syariah Institut Bankir Indonesia, Konsep, Produk dan Implementasi Operasional Bank Syariah, (Jakarta, Djambatan, 2001), hlm. 218 
prinsip syariah dan menghindari transaksi perbankan yang berbasis bunga.

3. Menstabilkan nila uang: dalam Islam uang dianggap sebagai alat tukar dan bukan sebagai komoditi/barang bisa dijual, dimana barang terdapat harga untuk setiap kegunaannya. Oleh karena itu sistem bebas riba mengarah pada kestabilan nilai uang dan memudahkan pertukaran menjadi unit account yang dapat diandalkan.

4. Pengembangan ekonomi: Bank islam turut serta memacu pertumbuhan ekonomi melalui produk-produknya seperti musyarakah, mudharabah dan lain sebagaainya. Dimana produk tersebut memiliki perbedaan dengan produk konvensional, yaitu pembagian keuntungan maupun pembagian resiko antar bank, depositor dan pengusaha. Hal ini dibuktikan dengan penanaman investasi bank kedalam perusahaan milik pengusaha sehingga jika bisnis berhasil maka perkembangan ekonomi niscaya juga akan maju.

5. Alokasi sumber daya secara optimal: Bank Islam mengoptimasi alokasi dari sumber daya yang langka melalui investasi dari sember daya keuangan menjadi proyek-proyek yang dianggap bisa memberikan profit yang tinggi, yang dibolehkan secara agama dan menguntungkan secara ekonomi.

6. Keseimbangan distribusi terhadap sumber daya: bank Islam memastikan adanya keseimbangan distribusi dari pendapatan dan sumber daya diantara pihak yang berpartisipasi bank, depositor, pengusaha sebagai contoh melalui pendekatan pembagian keuntungan.

7. Pendekatan optimis: Profit sharing mendorong bank-bank kepada proyek-proyek yang menghasilkan keuntungan dalam jangka panjang termasuk termasuk jangka pendek. Ini mengarahkan bank untuk melalukan analisis yang tepat sebelum mengambil proyek-proyek tersebut dimana yang menjamin keamanan keduanya bank dan 
investor secara keseluruhan. Hasil yang tinggi akan didistribusikan kepada shareholders sehingga memaksimalkan keuntungan sosial dan membawa kesejahteraan ekonomi. ${ }^{14}$

Analisis pembiayaan merupakan langkah penting untuk realisasi pembiayaan di bank syariah. Analisis pembiayaan dilakukan oleh pelaksana pembiayaan di bank syariah yang bertujuan untuk:

1. Menilai kelayakan usaha calon peminjam

2. Menekan resiko akibat tidak terbayarnya pembiayaan

3. Menghitung kebutuhan pembiayaan yang layak.

Tujuan utama dari analisis permohonan pembiayaan adalah memperoleh keyakinan apakah customer punya kemauan dan kemampuan memenuhi kewajibannya secara tertib, baik pembayaran pokok pinjaman maupun bagi hasil sesuai dengan kesepakatan dengan bank. Dalam pemberian pembiayaan kepada customer, ada resiko yang dihadapi yaitu tidak kembalinya uang yang dipinjamnkan kepda customer. Oleh karena itu keadaan dan perkembangan customer harus diikuti secara terus menerus mulai saat pembiayaan diberikan sampai pembiayaan lunas.

Selain merumuskan tujuan pembiayaan, pengelola pembiayaan juga dapat melakukan beberapa pendekatan analisis pembiayaan diantaranya:

1. Pendekatan jaminan, artinya bank dalam memberikan pembiyaan selalu memperhatikan kuantitas dan kualitas jaminan yang dimiliki oleh peminjam.

2. Pendekatan karakter, artinya bank mencermati secara sungguhsungguh terkait dengan karakter nasabah.

3. Pendekatan kemampuan pelunasan, artinya bank menganalisis kemampuan nasabah untuk melunasi jumlah pembiayaan yang telah diambil.

4. Pendekatan studi kelayakan, artinya bank memperhatikan kelayakan usaha yang dijalankan oleh nasabah peminjam

${ }^{14}$ Veithzal Rivai \& Rifki Ismal, Islamic Risk Management For Islamic Bank, (Jakarta: Gramedia Pustaka Utama, 2013), hlm. 25 
5. Pendekatan fungsi-fungsi bank, artinya bank memperhatikan fungsinya sebagai lembaga intermediary keuangan, yaitu mengatur mekanisme dana yang dikumpulkan dengan dana yang disalurkan. ${ }^{15}$

Selain itu dalam pemberian pembiayaan kepada seorang customer agar dapat dipertimbangkan telebih dahulu harus terpenuhi persyaratan yang dikenal dengan prinsip $6 \mathrm{C}$ yakni:

\section{Character}

Character adalah keadaan watak/sifat dari customer, baik dalam kehidupan pribadi maupun dalam lingkungan usaha. Kegunaan dari penilaian terhadap karakter ini adalah untuk mengetahui sampai sejauh mana iktikad/kemauan customer untuk memenuhi kewajibannya sesuai dengan perjanjian yang telah ditetapkan.

2. Capital

Capital adalah jumlah dana/modal sendiri yang dimiliki oleh caloh mudharib. Makin besar modal sendiri dalam perusahaan, tentu semakin tinggi kesungguhan calon mudharib menjalankan usahanya dan bank akan merasa lebih yakin memberikan pembiayaan.

3. Capacity

Capacity adalah kemampuan yang dimiliki calon mudharib dalam menjalankan usahanya guna memperoleh laba yang diharapkan. Kegunaan dari penilaian ini adalah untuk mengukur/mengetahui sampai sejauh mana calon mudharib mampu mengembalikan atau melunasi utang-utangnya secara tepat waktu, dari hasil usaha yang diperolehnya.

4. Collateral

Collateral adalah barang yang diserahkan mudharib sebagai agunan terhadap pembiayaan yang diterimanya. Collateral harus dinilai oleh bank untuk mengetahui sejauh mana risiko kewajiban finansial mudharib kepada bank. Penilaian terhadap agunan ini meliputi jenis, lokasi, bukti kepemilikan, dan status hukumnya.

5. Condition of Economy

Condition of Economy adalah situasi dan kondisi politik, sosial, ekonomi, dan budaya yang mempengaruhi keadaan perekonomian yang

${ }^{15}$ Muhammad, Manajemen Pembiayaan, hlm. 60 
memungkinkan pada suatu saat mempengaruhi kelancaran perusahaan calon mudharib.

\section{Constrain}

Constrain adalah batasan dan hambatan yang tidak memungkinkan suau bisnis untuk dilaksanakan pada tempat tertentu, misalnya pendirian suatu usaha pompa bensin yang di sekitarnya banyak bengkel-bengkel las atau pembakaran batu bata. ${ }^{16}$

\section{E. PROSEDUR PEMBIAYAAN BANK SYARIAH}

Salah satu aspek penting dalam perbankan syariah adalah proses pembiayaan yang sehat. Yang dimaksud dengan proses pembiayaan yang sehat adalah proses pembiayaan yang berimplikasi kepada investasi halal dan baik serta mengahasilkan return sebagaimana yang diharapkan, atau bahkan lebih. Pada perbankan syariah, proses pembiayaan yang sehat tidak hanya berimplikasi kondisi bank yang sehat tetapi juga berimplikasi pada peningkatan kinerja sektor riil yang dibiayai. ${ }^{17}$

Prosedur pembiayaan adalah suatu gambaran sifat atau metode untuk melaksanakan kegiatan pembiayaan. Setiap pejabat bank yang berhubungan dengan pembiayaan harus menempuh prosedur pembiayaan yang sehat, yang meliputi prosedur persetujuan pembiayaan, prosedur administrasi serta prosedur pengawasan pembiayaan. ${ }^{18}$

Persetujuan pembiayaan kepada setiap nasabah harus dilakukan melalui proses penilaian yang objektif terhadap berbagai aspek yang berhubungan dengan obyek pembiayaan, sehingga memberikan keyakinan kepada semua pihak yang terkait bahwa nasabah dapat memenuhi segala kewajibannya sesuai dengan persyaratatan dan jangka waktu yang disepakati.

Persetujuan pembiayaan hanya dilakukan oleh pejabat yang mempunyai wewenang untuk memutuskan pembiayaan. Keputusan pembiayaan harus didasarkan atas penilaian terhadap seluruh pembiayaan yang sedang dan akan dinikmati pemohon secara bersamaan. Besarnya

16 Veithzal Rivai \& Andria Permata Veithzal, Islamic Fincial Management, (Jakarta, Rajawali Press, 2008), hlm. 352

17 Suhartono Zulkifli, Panduan Praktis Transaksi Perbankan Syariah, (Jakarta, Zikrul Hakim, 2003), hlm. 138

${ }^{18}$ Zainul Arifin, Dasar-dasar Manajemen Bank Syariah, (Jakarta, Pustaka Alvabet, 2006), hlm. 217 
wewenang setiap pejabat pemutus atau pemberi persetujuan pembiayaan harus dinyatakan secara tertulis dalam surat keputusan direksi. ${ }^{19}$

1. Administrasi dan Proses Pembiayaan

Portofolio pembiayaan (financing) merupakan bagian terbesar dari aktiva bank, karena pembiayaan merupakan aktivitas utama dari usaha perbankan. Dengan demikian maka pendapatan bagi hasil atau keuntungan jual beli yang merupakan instrumen pembiayaan perbankan syariah merupakan sumber pendapatan yang dominan.

Kualitas pembiayaan sangat berpengaruh terhadap efektivitas pendapatan yang diharapkan. Oleh karena itu kualitas ini harus dijaga, agar jangan sampai menjadi pembiayaan bermasalah, yang akibatnya bukan saja menyebabkan tidak efektifnya pendapatan tetapi lebih dari itu dapat menyebabkan kerugian bank karena tidak terbayarnya kembali dana bank yang ditanamkan dalam pembiayaan itu. Faktorfaktor penyebab masalah harus dihilangkan, dan syarat-syarat yang sempurna merupakan bagian terpenting dalam Proses pemberian pembiayaan. Dengan kata lain, prinsip kehati-hatian harus menjadi perhatian utama dalam manajemen pembiayaan. ${ }^{20}$

2. Unsur-unsur Administrasi Pembiayaan

Administrasi dari portofolio pembiayaan dapat dibagi menurut tujuan dari fungsi manajemen secara umum, yaitu perencanaan, Pengorganisasian dan pengendalian. Perencanaan meliputi pertimbangan risiko dan pendapatan, serta alokasi pembiayaan. Pengorganisasian menyangkut pengaturan pelaksanaan rencana pencapaian tujuan melalui penentuan kebijakan dan proses, termasuk pengadaan fungsi-fungsi pendukung dan kegiatan penyajian (realisasi) pembiayaan melalui struktur organisasi. Pengendalian menyangkut Proses keputusan, pemantauan, pembinaan dan pengawasan pembiyaan.

a. Perencanaan Pembiayaan

Suatu perencanaan yang baik dilakukan melalui berbagai Proses kegiatan yang meliputi forecasting, objective, policies, programes, dan budget.

\footnotetext{
${ }^{19} \mathrm{Ibid}$

${ }^{20}$ Ibid, hlm. 209
} 
1) Forecasting

Forecasting adalah suatu peramalan usaha yang sistematis, untuk mencapai sesuatu yang paling mungkin diperoleh di masa yang akan datang, dengan melakukan penaksiran dan perhitungan yang rasional atas fakta yang ada. Fungsi perkiraan adalah untuk memberi informasi sebagai dasar pertimbangan dalam pengambilan keputusan.

Langkah pertama yang harus dilakukan oleh manajemen bank adalah melakukan analisis terhadap kondisi (kekuatan dan kelemahan yang dimiliki) perusahaan serta situasi (peluang dan tantangan) yang dihadapinya (SWOT analysis), berdasarkan data informasi yang ada (existing conditions), internal dan eksternal dalam rangka perumusan kebijakan dasar. Kondisi internal meliputi potensi dan fasilitas yang tersedia, strukfur aktiva, posisi dana-dana, struktur pendapatan dan biaya. Sedangkan kondisi eksternal meliputi penelaahan situasi moneter, lokal dan internasional, peraturan perundang-undangan, situasi dan kondisi perdagangan nasional dan internasional, situasi persaingan serta market share yang dikuasai oleh bank di wilayah operasinya.

2) Tujuan Pembiayaan

Langkah kedua adalah merumuskan tujuan pembiayaan. Tujuan pembiayaan merupakan bagian dari tujuan bank sebagai perusahaan, yaitu memperoleh keuntungan bagi kesejahteraan stakesholders-nya. Oleh karena itu tujuan pembiayaan harus mendukung visi, misi dan strategi usaha bank. Tujuan pembiayaan harus dirumuskan dengan jelas, realistis dan dapat diketahui oleh semua orang yang terlibat dalam organisasi, agar mereka dapat berpartisipasi dengan penuh kesadaraan.

3) Kebijakan Pembiayaan

Bidang kegiatan pembiayaan yang perlu dirumuskan dalam bentuk kebijakan dasar (basic policies) umumnya meliputi hal-hal berikut:

- Segmentasi Pembiayaan 
Kebijakan tentang segmentasi pembiayaan merupakan salah satu bentuk implementasi dari pelaksanaan misi dan usaha pencapaian visi bank. Segmentasi pembiayaan dapat ditetapkan dalam bentuk pilihan sektor usaha nasabah (line of business) atau tipe nasabah (size of business).

Bank harus menetapkan sektor industri dan atau tipe nasabah yang menjadi sasaran bagi pemasaran produk pembiayaannya. Melalui berbagai pertimbangan, bank dapat memutuskan untuk hanya melayani beberapa sektor industri tertentu saja dan tipe usaha kecil dan menengah saja, sedangkan usaha besar tidak. Dengan pertimbangannya sendiri bank lain juga dapat memutuskan untuk melayani semua sektor usaha dan semua jenis nasabah, baik usaha besar, usaha menengah, usaha kecil maupun perorangan. Kebijakan. Mengenai pilihan segmentasi pembiayaan berkaitan pula dengan jenis pembiayaan yang disediakan, daerah atau wilayah pelayanan, sistem penyampai an (deliaery system), dan distribusi pembiayaan.

- Jenis Pembiayaan yang Disediakan bagi Nasabah jenis pembiayaan yang disediakan oleh bank biasanya berkaitan erat dengan sektor ,usaha dan tipe nasabah yang ingin dilayani jenis nasabah tertentu cukup dilayani melalui beberapa jenis pembiayaan untuk memperoleh barang atau modal kerja saja, tetapi nasabah lain memerlukan ienis pembiayaan lain yang lebih terkait dengan kombinasi jasa informasi dan pelayanan bisnis perusahaan seperti trust and corporate services.

- Wilayah Pelayanan

Pertimbangan wilayah pelayanan berkaitan dengan Perencanaan jaringan kerja, pembukaan kantor-kantor cabang dan besar kecilnya kantor-kantor cabang tersebut. sentra-sentra ekonomi harus ditelaah terlebih dulu, seperti pertanian, industri, perdagangan dan sebagainya. Hal ini berkaitan dengan kebijakan desentralisasi manajemen dan pendelegasian wewenang. 
- Sistem Penyampaian (Delivery System) Produk \& Jasa Bank Kebijakan ini berkaitan dengan pola perluasan jangkauan pemasaran dan penyampaian produk dan jasa bank. Sebagian bank mengutamatan penggunaan jaringan organik yang dimilikinya sendiri seperti kantor cabang, kantor kas, dan sebagainya. Sebagian bank lain memilih melakukan outsourcing dengan menggunakan agen-agen sebagai remarketer.

- Distribusi Pembiayaan

Dalam menerapkan distribusi aktiva produktif perlu disusun kebijakan alokasi dana, baik menurut sektor ekonomi' sektor industri, maupun daerah atau wilayah pemasaran. Misalnya sekian Persen untuk pembiayaan sektor industri manufaktur, sekian Persen untuk perdagangan, sekian Persen untuk real estate, sekian Persen untuk investasi dan penyertaan, termasuk besarnya pembiayaan maksimum (legal lending limit) yang dapat diberikan kepada setiap nasabah, baik individu maupun kelompok, yang dalam hukum perbankan Indonesia dikenal dengin Batas Maksimurn-Pemberian Kredit (BMPK).

4) Programmes

Programmes adalah sederetan kegiatan yang dipaparkan untuk melaksanakan policies. Program itu merupakan rencana kegiatan (action plan) yang dinamis yang biasanya dilaksanakan secara bertahap, dan terikat dengan ruang (place) dan waktu (time). Program itu harus merupakan suatu kesatuan yang terkait erat dan tidak dapat dipisahkan dengan tujuan yang telah ditentukan dalam organisasi.

5) Budget

Budget adalah suatu taksiran atau perkiraan volume portofolio pembiayaan yang ingin dicapai selama kurun satu periode anggaran, termasuk biaya yang dikeluarkan dan pendapatan yang diharapkan diperoleh dimasa yang akan datang. Perkiraan tersebut disusun secara terinci, yang meliputi besaran-besaran yang dianggarkan terhadap setiap 
jenis pembiayaan, setiap segmen, setiap wilayah pemasaran dan sebagainya. Degaan demikian, budget dinyatakan dalam waktu, uang, material dan unit-unit yang malaksanakan pekerjaan guna memperoleh hasil yang diharapkan. ${ }^{21}$

\section{F. ANALISIS KELAYAKAN PEMBIAYAAN}

Dalam kegiatan penyaluran dana bank syariah melakukan investasi dan pembiayaan. Disebut investasi karena prinsip yang digunakan adalah prinsip penanaman dana atau penyertaan, dan keuntungan yang akan diperoleh bergantung pada kinerja usaha yang menjadi objek penyertaan tersebut sesuai dengan nisbah bagi hasil yang telah diperjanjikan sebelumnya. Disebut pembiayaan karena bank syariah menyediakan dana guna membiayai kebutuhan nasabah yang memerlukannya dan layak memperolehnya.

Dalam penyaluran pembiayaan kepada calon nasabah terdapat aspekaspek yang perlu diperhatikan untuk memutuskan calon nasabah memiliki tingkat kelayakan pembiayaan atau tidak, aspek-aspek tersebut meliputi:

1. Evaluasi pasar dan pemasaran hasil produksi

Kemampuan perusahaan menciptakan dana untuk mengembalikan pembiayaan sangat dipengaruhi oleh keberhasilan pemasaran hasil produksi mereka. Semakin maju dan berhasil pemasaran hasil produksi, akan semakin besar kemampuan perusahaan meningkatkan jumlah penjualan dan keuntungan mereka. Seorang analisis harus melihat aspek:

a. Internal, strategi pemasaran perusahaan dari 4P (marketing Mix) yaitu:

1) Products (produk yang dihasilkan perusahaan)

2) Place (strategi distribusi produk)

3) Price (strategi harga penjualan produk)

4) Promotion (strategi promosi produk)

b. Eksternal berupa:

1) Perkembangan kehidupan ekonomi umum

2) Perkembangan keadaan politik negara

${ }^{21}$ Ibid, hlm.213 
3) Perkembangan suasana persaingan pasar

4) Peraturan atau keputusan pemerintah

2. Evaluasi Manajemen perusahaan debitur

Manajemen merupakan faktor produksi yang paling menentukan dalam memelihara kelangsungan dan perkembangan hidup perusahaan. Beberapa macam kriteria pokok yang dapat digunakan oleh bank maupun para analisis pembiayaan untuk menilai kemampuan calon debitur dalam mengelola perusahaan antara lain:

a. Usia perusahaan

b. Kualifikasi dan kekompakan kerja pimpinan teras

c. Kedudukan perusahaan dipasar

d. Kemampuan mengelola harta perusahaan

e. Kemampuan mengelola sumber daya manusia

f. Kemampuan memperoleh keuntungan.

3. Analisis kondisi keuangan

Seorang analis pembiayaan mengevaluasi kondisi keuangan calon debitur dengan tujuan:

a. Kemampuan perusahaan menghasilkan keuntungan

b. Struktur pendanaan operasional perusahaan

c. Kemampuan untuk melunasi pinjaman yang jatuh tempo

d. Efisiensi pengelolaan harta perusahaan untuk masa lampau. ${ }^{22}$

Selain itu juga terdapak aspek lain dalam analisis kelayakan pembiayaan diantaranya:

1. Aspek yuridis

Di dalam aspek yuridis diberikan beberapa batasan untuk memudahkan pelaksanaan analisis, yaitu penelitian yang meliputi legalitas pendirian perusahaan (badan usaha), legalitas usaha, legalitas pengajuan permohonan pembiayaan dan legalitas barangbarang jaminan.

${ }^{22}$ Muhammad, Manajemen Pembiayaan hlm. 62 
2. Aspek pemasaran

Didalam penelitian aspek pemasaran, hal yang perlu diketahui adalah kemampuan perusahaan memasarkan barang produksi/jasa hasil usahanya, baik yang sekarang maupun yang direncanakan.

3. Aspek manajemen dan organisasi.

Setiap unit usaha memerlukan pimpinan/manajer yang bertugas mengelola usaha. Persyaratan yang diperukan bagi seorang manajer berbeda-beda kendatipun pada dasarnya sama, yaitu memiliki pengetahuan dan pengalaman yang memadai. Pengetahuan dapat diperoleh dari pendidikan formal maupun non formal, sedangkan pengalaman dapat diperoleh dari praktik. Kombinasi yang baik antara pengetahuan dan keterampilan tersebut menjadikan kompetensi yang memadai.

4. Aspek teknis

Lingkup aspek teknis dalam analisis pembiayaan adalah menilai apakah barang yang diproduksi customer dapat dibuat dengan kualitas yang baik dan dengan biaya produksi yang rendah sehingga laku dijual dan menguntungkan.

5. Aspek keuangan

Aspek finansial ini merupakan aspek yang sangat penting di dalam analisis permohonan pembiayaan meskipun aspek-aspek lain juga sangat menentukan. Evaluasi kondisi keuangan calon debitur dapat dilakukan dengan melihat laporan keuangan berupa neraca dan rugi laba perusahaan, anlalisis rasio keuangan, dan proyeksi arus kas calon debitur.

6. Aspek jaminan

Salah satu persyaratan yang ditetapkan dalam rangka pemberian pembiayaan perbankan adalah penyerahan jaminan oleh calon customer. Jaminan tersebut beraneka ragam jenisnya. Suatu jaminan yang diserahkan calon customer dalam rangka pemberian pembiayaan oleh bank harus diteliti dan dinilai dengan secara baik untuk mendapatkan nilai perkiraan yang wajar. Nilai perkiraan yang wajar ditetapkan untuk suatu jaminan dan akan merupakan pedoman untuk mengukur kewajarannya terhadap pemberian pembiayaan yang sedang dipertimbangkan apakah sudah cukup memadai atau 
belum memenuhi persyaratan nilai jaminan yang ditetapkan oleh lembaga keuangan.

7. Aspek sosial ekonomi dan analisis dampak lingkungan (AMDAL)

Perlu ditinjau dalam aspek ini adalah pengaruh perusahaan terhadap sosial ekonomi masyarakat setempat pada khususnya dan Indonesia pada umumnya. Adapun hal-hal yang perlu diperhatikan dalam aspek ini antara lain:

a. Kemungkinan penyerapan tenaga kerja

b. Apakah proyek tersebut dapat menumbuhkan kehidupan ekonomi masyarakat stempat. Atau sebaliknya akan mematikan sektorsektor usaha masyarakat setempat yang sudah ada saat ini.

c. Apakah proyek tersebut tidak bertentangan dengan adat istiadat dan agama masyarakat setempat.

d. Khusus mengenai analisis dampak lingkungan, harus diperhatikan peraturan/ketentuan pemerintah yang berlaku apakah telah mempunyai izin AMDAL dari instansi yang berwenang. ${ }^{23}$

\section{G. PENUTUP}

Pembiayaan atau financing, yaitu pendanaan yang diberikan oleh suatu pihak kepada pihak lain untuk mendukung investasi yang telah direncanakan, baik dilakukan sendiri maupun lembaga. Dengan kata lain, pembiayaan adalah pendanaan yang dikeluarkan untuk mendukung investasi yang telah direncanakan

Tujuan analisis pembiayaan yang dilakukan oleh pelaksana pembiayaan di bank syariah yaitu untuk:

1. Menilai kelayakan usaha calon peminjam

2. Menekan resiko akibat tidak terbayarnya pembiayaan

3. Menghitung kebutuhan pembiayaan yang layak.

${ }^{23}$ Veithzal Rivai \& Andria Permata Veithzal, Islamic hlm. 441 
Rahmat Ilyas

Aspek-aspek yang digunakan dalam analisis kelayakan pembiayaan diantaranya:

1. Aspek yuridis

2. Aspek pemasaran

3. Aspek manajemen dan organisasi.

4. Aspek teknis

5. Aspek keuangan

6. Aspek jaminan

7. Aspek sosial ekonomi dan analisis dampak lingkungan (AMDAL) 


\section{DAFTAR PUSTAKA}

Antonio Muhammad Syafi'i, Bank Syariah dari Teori ke Praktik, Jakarta, Gema Insani Press, 2001.

Arifin Zainul, Dasar-dasar Manajemen Bank Syariah, Jakarta, Pustaka Alvabet, 2006.

Ascarya, Akad E Produk Bank Syariah, Jakarta, PT. RajaGrafindo Persada, 2011.

Ilyas Rahmat, Kontrak Pembiayaan Murabahah Dan Musawamah, Jurnal BISNIS, Vol. 3, No. 2, Desember 2015.

, Konsep Pembiayaan Dalam Perbankan Syari'ah, Jurnal Penelitian, Vol. 9, No. 1, Februari 2015.

Karim Adiwarman A, Bank Islam: Analisis Fiqih dan Keuangan, Jakarta, PT. RajaGrafindo Persada, 2006.

Muhammad, Model-model Akad Pembiayaan di Bank Syariah, Yogyakarta, UII Press, 2009.

2005.

Perwataatmadja Karnaen \& Muhammad Syafi'I Antonio, Apa E Bagaimana Bank Islam, Yogyakarta, PT. Dana Bhakti Prima Yasa, 1992.

Rahman Afzalur, Doktrin Ekonomi Islam, Jilid 4, Yogyakarta, PT. Dana Bhakti Wakaf, 1995.

Rivai Veithzal \& Rifki Ismal, Islamic Risk Management For Islamic Bank, Jakarta, Gramedia Pustaka Utama, 2013.

Rivai Veithzal \& Andria Permata Veithzal, Islamic Fincial Management, Jakarta, Rajawali Press, 2008.

Saed Abdullah, Bank Islam dan Bunga: Studi Kritis dan Interpretasi Kontemporer tentang Riba dan Bunga, Yogyakarta, Pustaka Pelajar, 2008.

Tim Pengembangan Perbankan Syariah Institut Bankir Indonesia, Konsep, Produk dan Implementasi Operasional Bank Syariah, Jakarta, Djambatan, 2001.

Undang-undang Nomor 21 Tahun 2008 tentang Perbankan Syariah. 
Rahmat Ilyas

Zulkifli Suhartono, Panduan Praktis Transaksi Perbankan Syariah, Jakarta, Zikrul Hakim, 2003. 